\title{
Soil Bacterial Hydrolysis leading to Genuine Aglycone. III. 1,2) The Structures of Glycosides and Genuine Aglycone of Sanguisorbae Radix
}

\author{
Itriro Yosioka, Tamio Sugawara, ${ }^{3 a)}$ Akio Ohsuka, ${ }^{3 b)}$ \\ and IsAo KITAGAWA ${ }^{3 a)}$ \\ Faculty of Pharmaceutical Sciences, Osaka University ${ }^{3 a)}$ and \\ Faculty of Science, Osaka City University ${ }^{4 b)}$
}

(Received March 8, 1971)

\begin{abstract}
The structures of two glycosides, named ziyu-glycoside I and ziyu-glycoside II, obtained from Sanguisorbae Radix have been established as I and II respectively by virtue of the soil bacterial hydrolysis method. Furthermore, it has been revealed that the genuine aglycone of the glycosides is pomolic acid (XI) and is not tomentosolic acid (III).
\end{abstract}

The usefulness of the soil bacterial hydrolysis method leading to genuine sapogenin has been revealed in the previous papers on Senega root saponin, 1) Panax saponin, 1) and horsechestnut seeds saponin.2) To exploit the novel application of the method and to elucidate the scope and limitation, we have so far employed the method to some other saponins and glycosides. ${ }^{5}$ The present paper deals with the results on the glycosides obtained from Sanguisorbae Radix ("ziyu" 地榆) (air dried roots of Sanguisorba officinalis L., Rosaceae ${ }^{5}$ ) leading the structures I and II for the major glycosides, named ziyu-glycoside I and ziyu-glycoside II respectively.

It was in 1964 when two independent studies by Kondo and Takemoto ${ }^{6)}$ and Hirata, et al. ${ }^{7)}$ clarified the structure of sanguisorbigenin obtained from the acid hydrolysate of the total extract of Sanguisorbae Radix. Their final conclusions were based on the direct comparison of sanguisorbigenin with tomentosolic acid (III), which is a sapogenol of Vangueria tomentosa Hochst. (Rubiaceae) and the structure of which had already been determined by Barton and his co-workers. ${ }^{8)}$

As for the glycoside of Sanguisorbae Radix, Kotake and his co-workers ${ }^{9}$ have elucidated two glycosides, named waremokonin and sanguisorbin giving the structures IV and V re-

1) Part I: I. Yosioka, M. Fujio, M. Osamura, and I. Kitagawa, Tetrahedron Letters, 1966, 6303 (On Senega and Panax saponins).

2) Part II: I. Yosioka, K. Imai, and I. Kitagawa, Tetrahedron Letters, 1967, 2577 (On horse-chestnut seeds saponin).

3) Location: a) Toneyama, Toyonaka, Osaka; b) Nishi-ohgimachi 12, Kita-ku, Osaka.

4) a) On tea seeds saponin: I. Yosioka, A. Matsuda, M. Fujio, and I. Kitagawa, The 24 th Grand Assembly of the Pharmaceutical Society of Japan. Abstract Papers, Kyoto, 4, 1967, p. 464; I. Yosioka, A. Matsuda, and I. Kitagawa, The 88th Annual Meeting of the Pharmaceutical Society of Japan, Abstract Papers, Tokyo, 4, 1968, p. 256; b) On jegosaponin: I. Yosioka, K. Imai, S. Saijo, and I. Kitagawa, ibid., p. 255; c) On Ginseng saponin: I. Yosioka, K. Imai, I. Kitagawa, S. Shibata, O. Tanaka, and T. Ando, ibid., p. 255; d) On stevioside: I. Yosioka, S. Saijo, I. Kitagawa, and J.A. Waters, The 89th Annual Meeting of the Pharmaceutical Society of Japan, Abstract Papers, Nagoya, 4, 1969, p. 356.

5) “Chung Yao Chih (中獭誌)," Vol. 1, Peking (北京), 1959, p. 201.

6) Y. Kondo and T. Takemoto, Yakugaku Zasshi, 84, 367 (1964).

7) H. Wada, H. Nakata, and Y. Hirata, Yakugaku Zasshi, 84, 477 (1964).

8) D.H.R. Barton, H.T. Cheung, P.J.L. Daniels, K.G. Lewis, and J.F. McGhie, J. Chem. Soc., $1962,5163$.

9) S. Kusumoto, T. Fujiwara, A. Ohsuka, and M. Kotake, Nippon Kagaku Zasshi, 89, 1118 (1968). 


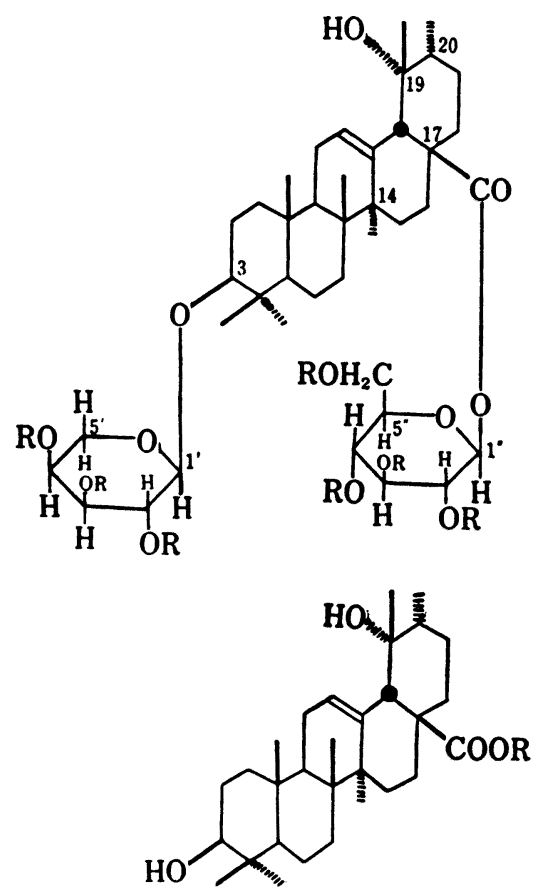

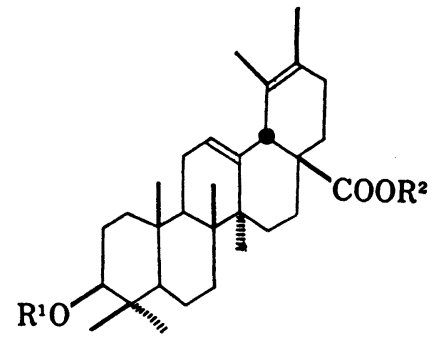

I: $\mathrm{R}=\mathrm{H}$ ziyu-glycoside I

II: $\mathrm{R}=\mathrm{H}, \mathrm{C}_{17}-\mathrm{COOH}$ in place of $\mathrm{C}_{17}-\mathrm{COO}-\beta$-Dglucopyranosyl (=ziyu-glycoside II) (=P-B) XIV: $R=A c$

$\mathrm{XVI}: \mathrm{R}=\mathrm{Ac}, \mathrm{C}_{17}-\mathrm{COOCH}_{3}$ in place of $\mathrm{C}_{17}-\mathrm{COO}-\beta$ D-glucopyranosyl

XVII : $\mathrm{R}=\mathrm{H}, \mathrm{C}_{17}-\mathrm{COOCH}_{3}$ in place of $\mathrm{C}_{17}-\mathrm{COO}$ $\beta$-D-glucopyranosyl

$\mathrm{XI}: \mathrm{R}=\mathrm{H}$ pomolic acid (=P-A)

$\mathrm{XV}: \mathrm{R}=\mathrm{CH}_{3}$

III : $\mathbf{R}^{\mathbf{1}}=\mathbf{R}^{\mathbf{2}}=\mathrm{H}$ tomentosolic acid (=sanguisorbigenin)

IV: $\mathbf{R}^{\mathbf{1}}=\mathrm{L}$-arabinosyl, $\mathbf{R}^{\mathbf{2}}=\mathrm{L}$-glucosyl, and one acetyl group attached at unknown hydroxyl (=the proposed structure of waremokonin ${ }^{10}$ )

V: $\mathbf{R}^{\mathbf{1}}=\mathbf{L}$-arabinosyl, $\mathbf{R}^{\mathbf{2}}=\mathrm{H}$

VI: $\mathbf{R}^{\mathbf{1}}=\mathbf{D}$-glucosyl, $\mathbf{R}^{2}=\mathrm{H}$

XII : $\mathrm{R}^{\mathbf{1}}=\mathrm{Ac}, \mathrm{R}_{\mathbf{2}}=\mathrm{CH}_{3}$<smiles>[R20]OC(=O)C12CCC(C)C(C)=C1C1=CCC3C4(C)CCC(O[R20])C(C)(C)C4CC[C@]3(C)[C@]1(C)CC2</smiles>

IX: $R^{\mathbf{1}}=\mathrm{R}^{\mathbf{2}}=\mathrm{H}$ vanguerolic acid XIII: $\mathrm{R}^{1}=\mathrm{Ac}, \mathrm{R}^{2}=\mathrm{CH}_{3}$

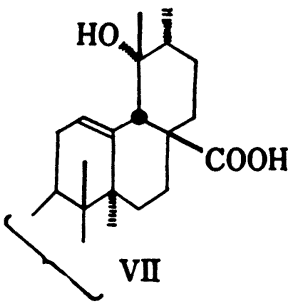<smiles>CCC1CCC([C@H]2CCCCC2(C)C)C(C(=O)O)CC1(C)O</smiles>

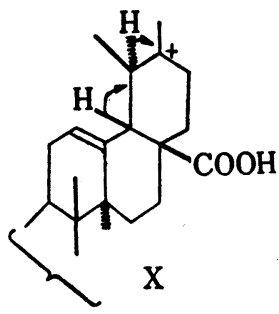

Chart 1 
spectively, while Takemoto and his co-workers have isolated another glycoside which they named also sanguisorbin and to which the structure VI was presented. ${ }^{10}$

On the other hand, several investigations have disclosed ${ }^{11)}$ the natural occurrence of $19 \alpha$ - or $20 \beta$-hydroxy-ursolic acid type derivatives having the part structure (VII or VIII), whereas the biogenetic consideration on tomentosolic acid (III) and vanguerolic acid (IX) presuming a common intermediate carbonium ion $(\mathrm{X})$ has been made by Barton, et al.$^{8)}$ and the consideration appeared to rationalize the natural occurrence of III and IX. Hence it has been supposed that the genuine aglycone of Sanguisorbae Radix may in fact possess the part structure of either VII or VIII.

To solve these problems, we have applied the soil bacterial hydrolysis method on the glycoside of Sanguisorbae Radix and reached the conclusion that the structures of ziyu-glycoside $\mathrm{I}^{12)}$ and ziyu-glycoside $\mathrm{II}^{13)}$ are expressed as I and II respectively and in addition the genuine aglycone is formulated as $19 \alpha$-hydroxy-ursolic acid (XI) (=pomolic acid ${ }^{11 d}$ ).

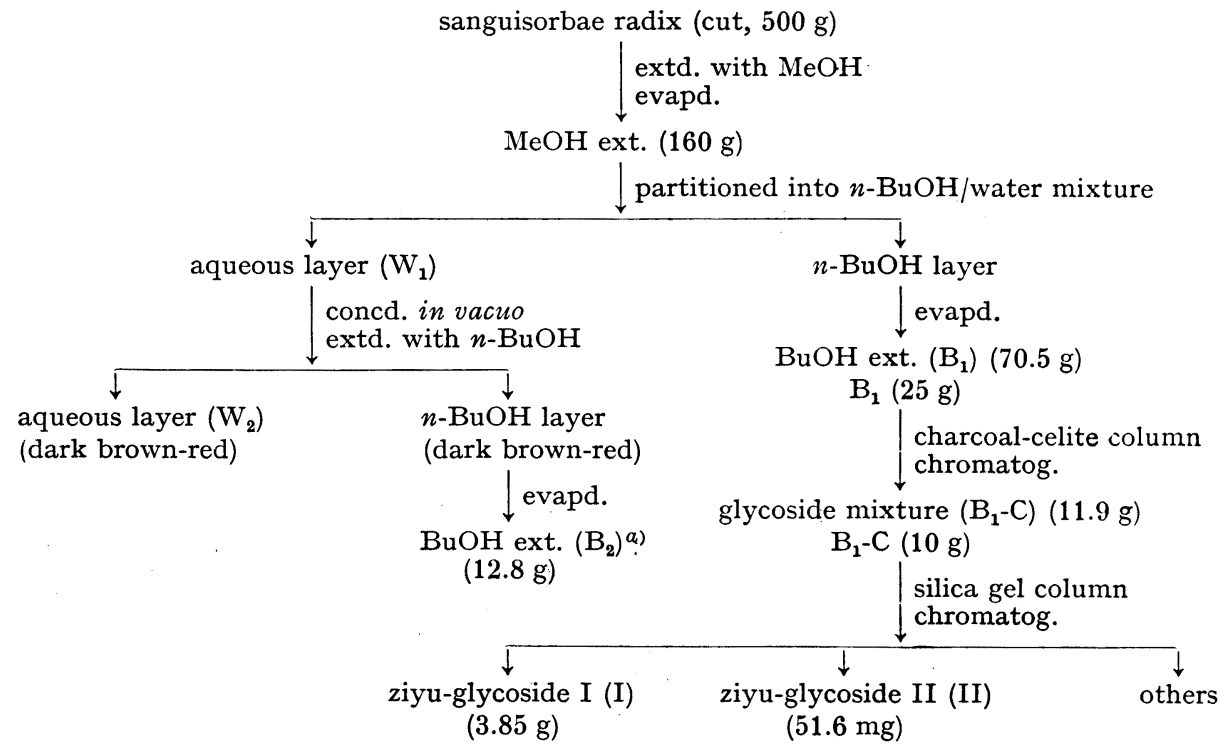

Chart 2. Isolation Procedure of Glycosides

a) $\mathrm{B}_{2}$ contains a trace amount of ziyu-glycoside $\mathrm{I}$ and a richer amount of more polar substances as revealed by TLC

The chromatographic separation of the glycoside portion obtained through the procedure as schemed in Chart 2 furnished so far two glycosides designated as ziyu-glycoside I and

10) Y. Inamori, T. Tanaka, and T. Takemoto, The 19th Annual Meeting of the Kinki Branch of the Pharmaceutical Society of Japan, Abstract Papers, Osaka, 1969, 10, p. 30.

11) a) P. Potier, B.C. Das, A.M. Bui, M.M. Janot, A. Pourrat, and H. Pourrat, Bull. Soc. Chim. France, 1966, 3458; b) J.S. Tandon, K.P. Agarwal, and M.M. Dhar, Indian J. Chem., 4, $483(1966)$; $c)$ W. Lawrie, J. McLean, and M.E. Younes, J. Chem. Soc. (C), 1967, 851; d) C.H. Brieskorn and H. Wunderer, Chem. Ber., 100, $1252(1967)$; e) T. Oyama, H. Aoyama, K. Yamada, T. Mitsuhashi, and N. Sugiyama, Tetrahedron Letters, 1968, 4639; f) K. Takahashi, M. Ogura, and Y. Tanabe, Chem. Pharm. Bull. (Tokyo), 17, 2223 (1969); g) J. Bermejo, J.L. Breton, G. de Fuente, and A.G. Gonzalez, Tetrahedron Letters, 1967, 4649.

12) Although Kotake, et al. ${ }^{10)}$ reported the isolation of a monoacetylated compound named waremokonin (cf. Chart 1), ziyu-glycoside I presented here carries no acetoxyl function as revealed by its physical data. Consequently, the direct comparison of ziyu-glycoside I with waremokonin was made using the fully acetylated derivatives of both as described later. Furthermore, it follows that the structure of waremokonin should be revised to the monoacetylated form of the structure $\mathrm{I}$.

13) Since there is a confusion in the literatures ${ }^{10,11)}$ concerning sanguisorbin, we propose the name "ziyuglycoside II" for the second glycoside. 
ziyu-glycoside II. Ziyu-glycoside I(I), $\mathrm{C}_{41} \mathrm{H}_{66} \mathrm{O}_{13} \cdot 2 \mathrm{H}_{2} \mathrm{O}, \operatorname{mp} 256-260^{\circ},[\alpha]_{\mathrm{D}}+18^{\circ}(c, 2.5$ in pyridine) exhibits an ester carbonyl absorption band at $1735 \mathrm{~cm}^{-1}$ in addition to a broad hydroxyl absorption band in its infrared (IR) spectrum. On acid hydrolysis, it gave a mixture of the dienic triterpenoids, which was separated through methylation and acetylation followed by the repeated fractional recrystallization into methyl 3-O-acetyl-tomentosalote

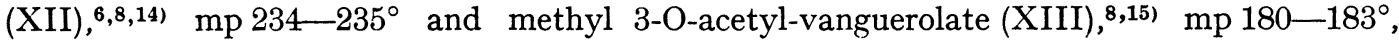
$\lambda_{\max }^{\mathrm{E}: \mathrm{H}} 225 \mathrm{~m} \mu(\varepsilon, 9690)$. The paper partition chromatography (PPC) of the aqueous portion of the hydrolysate disclosed the composition as D-glucose and L-arabinose. Furthermore, the fully methylated derivative of ziyu-glycoside I prepared after the Hakomori's procedure ${ }^{16}$ ) afforded, upon methanolysis, methyl 2,3,4-tri-O-methyl-L-arabopyranoside and methyl 2,3,4, 6-tetra-O-methyl-D-glucopyranoside. Since the ultraviolet (UV) absorption spectrum of ziyuglycoside I shows only the end absorption $(\varepsilon, 6060$ at $212 \mathrm{~m} \mu$ in EtOH), it is inferred that the aglycone moiety might have suffered the secondary transformation during the hydrolysis.

Ziyu-glycoside I heptaacetate (XIV), mp 149.5-151.5 , prepared with acetic anhydride and pyridine at room temperature shows a weak absorption band at $3656 \mathrm{~cm}^{-1}$ in its IR spectrum presumably ascribable to a tertiary hydroxyl. The nuclear magnetic resonance (NMR) spectrum of XIV exhibits a singlet at $8.77 \tau$ due to a methyl function attached to a carbon bearing a tertiary hydroxyl, ${ }^{11}$ ) whereas no signal assignable to a vinylic methyl is observed. Accordingly, it follows that the ring $\mathrm{E}$ structure of tomentosolic acid or vanguerolic acid type is considered as artefact. Furthermore, it is important to mention that the heptaacetate (XIV) obtained here was identified with acetyl-waremokonin prepared by Kotake, et al. ${ }^{9)}$ through the direct comparison (thin-layer chromatography (TLC), IR and mixed mp), thus demonstrating that acetyl-waremokonin also carries an intact hydroxyl function in the $\mathrm{E}$ ring of the aglycone moiety.

Next, to clarify the whole structure of ziyu-glycoside I, the soil bacterial hydrolysis has been performed although the glycoside was sparingly soluble in the aqueous medium. Thus, the preparative TLC separation of the total hydrolysate of ziyu-glycoside I (see experimental section) furnished an aglycone $\mathrm{P}-\mathrm{A}(\mathrm{XI}), \mathrm{C}_{30} \mathrm{H}_{48} \mathrm{O}_{4} \cdot \mathrm{H}_{2} \mathrm{O}, \mathrm{mp} 274-275^{\circ}$, and a glycoside P-B (II), $\mathrm{C}_{35} \mathrm{H}_{56} \mathrm{O}_{8} \cdot \mathrm{H}_{2} \mathrm{O}, \mathrm{mp} 243-245^{\circ}$. The mass spectrum of $\mathrm{P}-\mathrm{A}$ (XI) gives, in addition to two ion peaks at $m / e 472$ (molecular ion) and $454\left(\mathrm{M}^{+}-\mathrm{H}_{2} \mathrm{O}\right)$, the significant peaks at $m / e 207$ (i) and 264 (ii) which are characteristic fragment ions due to the reverse Diels-Alder type fragmentation. ${ }^{17)}$ Meanwhile, the methyl ester of $\mathrm{P}-\mathrm{A}, \mathrm{mp} 127-128.5^{\circ}$, obtained by the diazomethane treatment, shows a quite resembled mass spectrum to methyl pomolate (XV), ${ }^{11 d, f)}$ which was initially isolated from apple peal by Brieskorn and Wunderer. ${ }^{11 d}$ ) In fact, the direct comparison (TLC, IR and mixed $\mathrm{mp}$ ) of both samples established the identity, thus confirming the aglycone structure of ziyu-glycoside I being formulated as XI.

P-B, on the other hand, was found identical with ziyu-glycoside II (II) in all respects (TLC, IR, and mixed $\mathrm{mp}$ ). Acid hydrolysis of ziyu-glycoside II furnished L-arabinose and a dienic mixture as was obtained from ziyu-glycoside I. The IR spectrum of the methyl ester acetate of ziyu-glycoside II (XVI)(amorphous) indicates the existence of a tertiary hydroxyl. The possible location of the arabinoside linkage is assigned at C-3 since II possesses the free carboxylic function which was smoothly methylated by diazomethane as revealed by the IR absorption band alteration $\left(1685 \mathrm{~cm}^{-1}\right.$ in II while $1715 \mathrm{~cm}^{-1}$ in ziyu-glycoside II methyl ester (XVII)). The NMR spectrum of XVI (see experimental section) affords. the adequate evidence on the structure of ziyu-glycoside II. Thus, a three proton singlet at $8.77 \tau$ is assigned to a methyl attached to a carbon carrying a tertiary hydroxyl, while

14) Identified by the direct comparison (IR, TLC, and mixed $\mathrm{mp}$ ) with the authentic sample cordially provided by Prof. T. Takemoto.

15) Identified by the physical data comparison with methyl 3-O-acetyl-vanguerolate.9)

16) S. Hakomori, J. Biochem. (Japan), 55, 205 (1964).

17) H. Budzikiewicz, J.W. Wilson, and C. Djerassi, J. Am. Chem. Soc., 85, 3688 (1963). 
the coupling constant $(J=7 \mathrm{~Hz})$ of a doublet at $5.59 \tau^{18)}$ due to the anomeric proton reveals the $\alpha$-L-arabinosidic linkage. The location of $\mathrm{C}_{19}-\alpha$-tertiary hydroxyl is corroborated by three reasons: (i) Ziyu-glycoside II corresponds to a partially hydrolyzed substance of ziyuglycoside I towards pomolic acid (XI); (ii) A relatively narrow one proton singlet at $7.44 \tau$ due to $\mathrm{C}_{18}-\beta \mathrm{H}$ is attributed to its location adjacent to a tetra-substituted carbon ${ }^{11 f, g)}$; (iii) A singlet $(3 \mathrm{H})$ at $8.81 \tau$ assigned to $\mathrm{C}_{14}-\mathrm{CH}_{3}$ is observed in the lower region than the ordinary value (8.92 $\tau$ in methyl 3-O-acetyl-ursolate ${ }^{19)}$ ), suggesting that $\mathrm{C}_{14}-\mathrm{CH}_{3}$ situates in the vicinity of the hydroxyl function i.e. at $\mathrm{C}_{19}-\alpha$ rather than $\left.\mathrm{C}_{19}-\beta .11 a, 0,20\right)$ The arabinoside linkage at $\mathrm{C}-3$ is further confirmed by a characteristic triplet-like signal $(1 \mathrm{H})$ at $6.93 \tau$ assignable to $\mathrm{C}_{3}-\alpha \mathrm{H}$ geminar to a glycosidic function rather than an acetoxyl function. Consequently, the structure of ziyu-glycoside II is now assigned 3-O- $\alpha$-L-arabopyranosyl-pomolic acid (II). The mass spectrum of ziyu-glycoside II methyl ester acetate (XVI), giving the remarkable fragment ions at $m / e 468$ (iii) and 259 (iv) ${ }^{21)}$ along with the molecular ion at $m / e 744$ also cor-<smiles>[CH2]C1=CC2CCC(O)C(C)(C)C2CC1</smiles>

$\mathrm{i}: m / e 207$

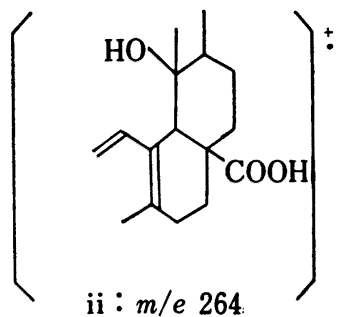

ii $: m / e 264$ roborate the formulation.

Finally, the structure of ziyu-glycoside $\mathrm{I}$ is proposed as 3-O- $\alpha$-L-arabopyranosyl-28$\mathrm{O}-\beta$-D-glucopyranosyl-pomolic acid (I) as based on the following reasons. The NMR spectrum of ziyu-glycoside I heptaacetate (XIV) exhibits a three proton singlet at $8.77 \tau$ assignable to $\mathrm{C}_{19}-\mathrm{CH}_{3}$ geminar to a hydroxyl in addition to a triplet-like signal due to $\mathrm{C}_{3}-\alpha \mathrm{H}$ at $6.94 \tau(1 \mathrm{H})$ similarly as in ziyu-glycoside II methyl ester acetate (XVI). Ziyu-glycoside $\mathrm{I}$ is unaffected by the diazomethane treatment suggesting that the carbonyl function is occupied. Besides, XIV shows a doublet $(J=6 \mathrm{~Hz})$ at $5.58 \tau$ due to the anomeric proton on the $\alpha$-L-arabopyranoside linkage, ${ }^{18)}$ and another $\operatorname{doublet}(J=$ $8 \mathrm{~Hz}$ ) at $4.50 \tau^{1)}$ attributable to $\beta$-D-glucopyranoside linkage attached at $\mathrm{C}_{\mathbf{1 7}}-\mathrm{COOH}$.

In a parallel experiment, the Smith degradation of ziyu-glycoside I (I) after the de Mayo's modification ${ }^{22)}$ was also attempted. However the results were unsatisfactory in

the present case as described in the experimental section.

In conclusion, tomentosolic acid (=sanguisorbigenin) (III) which has hitherto been known as the aglycone of the major glycoside of Sanguisorbae Radix, is now demonstrated as an

18) a) R.U. Lemiux, R.K. Killing, H.J. Bernstein, and W.G. Schneider, J. Am. Chem. Soc., 80, 6098 (1958); b) N. Mori, S. Omura, O. Yamamoto, T. Suzuki, and Y. Tsuzuki, Bull. Chem. Soc. Japan, 36, 1047 (1963); c) K. Miyahara and T. Kawasaki, Chem. Pharm. Bull. (Tokyo), 17, 1369 (1969).

19) a) H.T. Cheung and D.G. Williamson, Tetrahedron, 25, 119 (1969); b) R. Savoir, R. Ottinger, B. Tursch, and G. Chiuvdogu, Bull. Soc. Chim. Belges, 76, 371 (1967).

20) a) Y. Kawazoe, Y. Sato, M. Natsume, H. Hasegawa, T. Okamoto, and K. Tsuda, Chem. Pharm. Bull. (Tokyo), 10, 338 (1962); b) T. Okamoto and Y. Kawazoe, Chem. Pharm. Bull. (Tokyo), 11, 643 (1963).

21) a) H. Budzikiewicz, C. Djerassi, and D.H. Williams, "Structure Elucidation of Natural Products by Mass Spectrometry," Vol. 2, Holden-Day Inc., San Francisco, 1964, p. 203; b) T. Kawasaki, T. Komori, Y. Ida, Y. Inatsu, K. Miyahara, and T. Nohara, International Conference on Mass Spectroscopy, Preprints, Kyoto, 9, 1969, p. 221.

22) J.J. Dugan and P. de Mayo, Can. J. Chem., 43, 2033 (1965). 
artefact aglycone produced during the acid hydrolysis procedure and the genuine aglycone is pomolic acid (XI). Moreover, the structures of two major glycosides, ziyu-glycoside I and ziyu-glycoside II, are determined as I and II respectively.

It seems worthwhile to mention that the present study discloses the availability of the soil bacterial hydrolysis method upon the less soluble glycosides such as the present ziyuglycoside I (see experimental section). The study on the other less soluble glycosides is now in progress.

\section{Experimental $\left.{ }^{23}\right)$}

Isolation of Glycosides, Ziyu-Glycoside I (I) and Ziyu-Glycoside II (II) from Sanguisorbae Radix-Commercial Sanguisorbae Radix (purchased from Tochimoto-Tenkaido Co., Osaka) (cut, $500 \mathrm{~g}$ ) was extracted 4 times with methanol under reflux. Evaporation of the solvent gave a reddish-brown residue $(160 \mathrm{~g})$ which was partitioned into $n-\mathrm{BuOH}$ and water as usual. Upon evaporation under the reduced pressure, the $n-\mathrm{BuOH}$ soluble portion furnished a dark reddish-brown residue $\left(\mathrm{B}_{1}, 70.5 \mathrm{~g}\right)$ (cf. Chart 2). The fraction $B_{1}(25 \mathrm{~g})$ was then purified by passing through an active charcoal-celite column ( $500 \mathrm{~g}$ of charcoal, Tokusei-Shirasagi, Takeda Chem. Ind.; $100 \mathrm{~g}$ of celite 535, Wako Pure Chem. Ind.) with the successive aid of $\mathrm{MeOH}$ (totally $24 \mathrm{l}$ ) and $\mathrm{MeOH}-\mathrm{CHCl}_{3}(1: 1)$ mixture (totally $6.3 \mathrm{l}$ ). The combined fractions of the later eluates with $\mathrm{MeOH}$ gave a glycoside mixture $\left(\mathrm{B}_{1}-\mathrm{C}, 11.9 \mathrm{~g}\right)$, which was revealed by TLC $\left(\mathrm{CHCl}_{3}-\mathrm{MeOH}(4: 1)\right)$ to contain mainly a glycoside having $R f 0.40$ and appearing as a purple spot by detection with $1 \% \mathrm{Ce}\left(\mathrm{SO}_{4}\right)_{2} /$ $10 \% \mathrm{H}_{2} \mathrm{SO}_{4}$ under heating. The fraction $\mathrm{B}_{1}-\mathrm{C}(10.0 \mathrm{~g})$ was chromatographed on silica gel $(330 \mathrm{~g})$ developing with $\mathrm{CHCl}_{3}$ and $\mathrm{CHCl}_{3}-\mathrm{MeOH}(19: 1-1: 1)$ mixture successively. The eluate with $\mathrm{CHCl}_{3}-\mathrm{MeOH}(9: 1)$ mixture afforded ziyu-glycoside I fraction (single spot on TLC) which was recrystallized with $\mathrm{MeOH}$ to give colorless needles $(3.85 \mathrm{~g})$ of ziyu-glycoside I. Analytical sample melted at $256-260^{\circ},[\alpha]_{\mathrm{D}}+18^{\circ}(c, 2.5$ in pyridine). Anal. Calcd. for $\mathrm{C}_{41} \mathrm{H}_{68} \mathrm{O}_{13} \cdot 2 \mathrm{H}_{2} \mathrm{O}: \mathrm{C}, 61.33 ; \mathrm{H}, 8.78$. Found: $\mathrm{C}, 61.21 ; \mathrm{H}, 8.46$. IR $v_{\max }^{\mathrm{KBF}} \mathrm{cm}^{-1}$ : $3490(\mathrm{OH}), 1735$ (-COO-), 1077 (br). UV in EtOH: $\varepsilon, 6060$ at $212 \mathrm{~m} \mu$.

The fraction eluted with $\mathrm{CHCl}_{3}-\mathrm{MeOH}(19: 1)$ mixture from the above described silica gel column afforded a minor glycoside, which was recrystallized with methanol to give ziyu-glycoside II as colorless leaflets, $\mathrm{mp} 243-245^{\circ},[\alpha]_{\mathrm{D}}+25^{\circ}\left(c, 0.2\right.$ in DMSO), IR $v_{\max }^{\mathrm{RBr}} \mathrm{cm}^{-1}: 3450(\mathrm{OH}), 1685(\mathrm{COOH}), 1080$. Anal. Calcd. for $\mathrm{C}_{35} \mathrm{H}_{56} \mathrm{O}_{8} \cdot \mathrm{H}_{2} \mathrm{O}: \mathrm{C}, 67.49 ; \mathrm{H}, 9.39$. Found: $\mathrm{C}, 66.99 ; \mathrm{H}, 9.38$.

Acetylation of Ziyu-Glycoside I (I) giving the Heptaacetate (XIV) - A solution of ziyu-glycoside I (I) $(400 \mathrm{mg})$ in pyridine $(4 \mathrm{ml})$ and $\mathrm{Ac}_{2} \mathrm{O}(2 \mathrm{ml})$ was kept at $60^{\circ}$ for $3 \mathrm{hr}$, poured into ice-water, and treated as usual. Repeated recrystallization of the product with $n$-hexane yielded colorless fine crystals of the heptaacetate (XIV) $(559 \mathrm{mg})$ of $\mathrm{mp} 149.5-151.5^{\circ}$, [ $\left.\alpha\right]_{\mathrm{D}}+29^{\circ}\left(c, 0.55\right.$ in $\left.\mathrm{CHCl}_{3}\right)$. Anal. Calcd. for $\mathrm{C}_{55} \mathrm{H}_{80} \mathrm{O}_{20}$ : C, $62.26 ; \mathrm{H}, 7.55$. Found: C, 61.96; H, 7.51. IR $\nu_{\max }^{\mathrm{CClt}} \mathrm{cm}^{-1}: 3656(\mathrm{w})(\mathrm{OH}), 1760,1250,1222\left(\mathrm{OCOCH}_{3},-\mathrm{COO}-\right)$, 1058. NMR $\left(\mathrm{CDCl}_{3}, 100 \mathrm{MHz}\right) \tau: 9.30,9.22,9.08,9.04,8.87\left(18 \mathrm{H}\right.$, totally $\left.6 \times \mathrm{CH}_{3}\right), 8.77\left(3 \mathrm{H}, \mathrm{s},=\mathrm{C}_{(19)}\right.$ $\left.(\mathrm{OH}) \mathrm{CH}_{3}\right), 8.00,7.99,7.97,7.90\left(21 \mathrm{H}\right.$, each s, totally $\left.7 \times \mathrm{OCOCH}_{3}\right), 6.94\left(1 \mathrm{H}, \mathrm{t}\right.$-like, $\left.\mathrm{C}_{(3)}-\alpha \mathrm{H}\right), 6.25(1 \mathrm{H}, \mathrm{m}$, $\left.\mathrm{C}_{\left(5^{\prime \prime}\right)}-\mathrm{H}\right), 6.52,6.04\left(2 \mathrm{H}, \mathrm{AB}\right.$ part in ABX system, $\left.J_{\mathrm{AB}}=14 \mathrm{~Hz}, \mathrm{C}_{\left(5^{\prime}\right)}-\mathrm{H}_{2}\right), 5.99,5.77(2 \mathrm{H}, \mathrm{AB}$ part in ABX system, $\left.J_{A B}=13 \mathrm{~Hz}, J_{A X}=4 \mathrm{~Hz}, J_{B X}=2 \mathrm{~Hz}, \mathrm{C}_{\left(6^{\prime \prime}\right)}-\mathrm{H}_{2}\right), 5.58\left(1 \mathrm{H}, \mathrm{d}, J_{=6 \mathrm{~Hz}}, \mathrm{C}_{\left(1^{\prime}\right)}-\mathrm{H}\right), 4.66-5.08\left(7 \mathrm{H}, \mathrm{C}_{(12)}\right.$, $\left.\mathrm{C}_{\left(2^{\prime}\right)}, \mathrm{C}_{\left(3^{\prime}\right)}, \mathrm{C}_{\left(4^{\prime}\right)}, \mathrm{C}_{\left(2^{\prime \prime}\right)}, \mathrm{C}_{\left(3^{\prime \prime}\right)}, \mathrm{C}_{\left(\mathrm{(}^{\prime \prime}\right)}-\mathrm{H}_{7}\right), 4.50\left(1 \mathrm{H}, \mathrm{d}, J=8 \mathrm{~Hz}, \mathrm{C}_{\left(1^{\prime \prime}\right)}-\mathrm{H}\right)$.

The heptaacetate (XIV) obtained above was identified with acetyl-waremokonin prepared by Kotake, et al.9) by mixed $\mathrm{mp}$, TLC, and IR ( $\mathrm{KBr})$.

Acid Hydrolysis of Ziyu-Glycoside I (I) - A mixture of I $(400 \mathrm{mg})$ in $3 \% \mathrm{HCl}-\mathrm{MeOH}(40 \mathrm{ml})$ was refluxed for $30 \mathrm{~min}$. Methanol was then removed under the reduced pressure during the addition of small amount of water. The product was diluted with water and the precipitates were taken up with ether. After the usual work-up, the ether extract gave $220 \mathrm{mg}$ of the hydrolysate, which was crystallized from methanol to yield a dienic triterpenoid mixture. Methylation of the mixture with diazomethane followed by acetylation with $\mathrm{Ac}_{2} \mathrm{O}$-pyridine in the usual manner afforded a methyl ester acetate $(80 \mathrm{mg})$. Repeated fractional recrystallization using EtOAc-MeOH (1:2) mixture gave colorless needles (49 mg) (less soluble component in $\mathrm{MeOH}), \mathrm{mp} 234-235^{\circ}$, UV in EtOH : $\varepsilon, 9630$ at $210 \mathrm{~m} \mu$. IR $\nu_{m a x}^{\mathrm{ccl} \mathrm{cm}^{-1}}$ : no hydroxyl, 1730, $1242\left(\mathrm{OCOCH}_{3}\right.$, $\left.\mathrm{COOCH}_{3}\right)$. NMR $\left(\mathrm{CDCl}_{3}\right) \tau: 9.16,9.13,9.02\left(15 \mathrm{H}\right.$, totally $\left.\mathrm{CH}_{3} \times 5\right), 8.38,8.34\left(3 \mathrm{H}\right.$ each, $\left.\mathrm{s},-\mathrm{C}=\mathrm{C}-\mathrm{CH}_{3} \times 2\right)$,

23) All melting points were taken on the Yanagimoto Micro-melting point apparatus (a hot-stage type) and recorded as read. Specific rotations were measured with the Rex Photoelectric Polarimeter NEP$2(1=1 \mathrm{dm})$, the IR spectra were taken with the Hitachi EPIS2 and EPI-G31 IR Spectrophotometer. The NMR spectra were recorded with the Varian HA-100 and A-60 NMR Spectrometer (tetramethylsilane as the internal standard), the UV spectra were recorded with the Shimazu RSF-7B Spectrophotometer and with the Hitachi EPS-032 Spectrophotometer, and the Mass spectra with the Hitachi RMU-6D Spectrometer. TLC plates were made with silica gel for TLC (Camag) and detected by spraying $1 \%$ $\mathrm{Ce}\left(\mathrm{SO}_{4}\right)_{2} / 10 \% \mathrm{H}_{2} \mathrm{SO}_{4}$ solution followed by heating. For column chromatography, silica gel (Merck $70-325$ mesh) was used. 


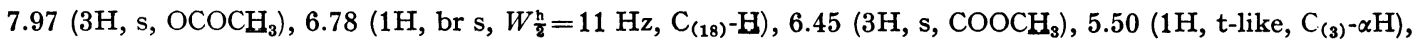
$4.51\left(1 \mathrm{H}, \mathrm{t}\right.$-like, $\left.=\mathrm{C}_{(12)}-\mathrm{H}\right)$. The compound obtained here was identified with authentic methyl 3-O-acetyltomentosolic acid (XII) by mixed $\mathrm{mp}$, TLC, and IR (KBr).

From the more soluble part in $\mathrm{MeOH}$ was obtained colorless prisms $(18 \mathrm{mg}), \mathrm{mp} 180-183^{\circ}$. UV $\lambda_{\max }^{\mathrm{gtoB}}$

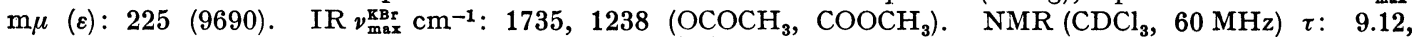
9.03, 9.00, $8.86\left(18 \mathrm{H}\right.$, totally $\left.6 \times \mathrm{CH}_{3}\right), 8.27\left(3 \mathrm{H}, \mathrm{s},-\mathrm{C}=\mathrm{C}-\mathrm{CH}_{3}\right), 7.96\left(3 \mathrm{H}, \mathrm{s},-\mathrm{OCOCH}_{3}\right), 6.48(3 \mathrm{H}, \mathrm{s},-\mathrm{COOCH})_{3}$, $5.44\left(1 \mathrm{H}, \mathrm{t}\right.$-like, $\left.\mathrm{C}_{(3)}-\alpha \mathrm{H}\right), 4.64\left(1 \mathrm{H}, \mathrm{t}\right.$-like, $\left.=\mathrm{C}_{(12)}-\mathrm{H}\right)$. The substance obtained here was assigned as methyl 3-O-acetyl-vanguerolate (XIII) based on the physical data comparison with the literature, ${ }^{8)} \mathrm{mp} 188-191^{\circ}$; $\mathrm{UV} \lambda_{\max }^{\mathrm{EtOH}} \mathrm{m} \mu(\varepsilon): 225(7800) ; \mathrm{IR} \nu_{\max }^{\mathrm{Nudol}} \mathrm{cm}^{-1}: 1720$; $\mathrm{NMR}\left(\mathrm{CCl}_{4}\right), \tau: 8.31$ (one vinyl-attached $\mathrm{CH}_{3}$ ), 4.66 (one vinyl $\mathrm{H})$.

The aqueous layer of the hydrolysate was passed through a column of Dowex 44 (OH form) to remove acid, concentrated in vacuo and examined by PPC (Toyo Roshi, No. 51 , developing with $n$-BuOH-AcOHwater $(5: 1: 2)$ for $24 \mathrm{hr})$ confirming the composition to be glucose $(R f: 0.18)$ and arabinose $(R f: 0.22)$ (detected by aniline hydrogen phthalate).

Acid Hydrolysis of Ziyu-Glycoside II (II)—A mixture of II (5.5 mg) in $3 \% \mathrm{HCl}-\mathrm{MeOH}(10 \mathrm{ml})$ was refluxed $30 \mathrm{~min}$ and treated as above. Ether extraction of the reaction mixture gave a crude hydrolysate (3 mg), which showed the same TLC pattern as that of the hydrolysate obtained above from ziyu-glycoside I (I). Recrystallization of the product gave the same dienic triterpenoid mixture as from I. PPC of the aqueous layer of the hydrolysate as above showed the composition to be arabinose.

Soil Bacterial Hydrolysis of Ziyu-Glycoside I (I)—Necessary soil bacterial stam was selected by the procedure as described before. ${ }^{1,2}$ ) The stam thus selected was cultivated stationary in a larger scale at $31^{\circ}$ on the same synthetic medium as used for the selection $\left(\mathrm{KH}_{2} \mathrm{PO}_{4} 0.3 \mathrm{~g}, \mathrm{MgSO}_{4} \cdot \mathrm{H}_{2} \mathrm{O} 0.21 \mathrm{~g}, \mathrm{NaCl} 0.3 \mathrm{~g}\right.$, $\left(\mathrm{NH}_{4}\right)_{2} \mathrm{HPO}_{4} 1.2 \mathrm{~g}, \mathrm{FeSO}_{4} 0.009 \mathrm{~g}$, ziyu-glycoside I (I) $0.9 \mathrm{~g}$ (only carbon source) and water making a total volume of $300 \mathrm{ml}$, followed by adjustment to $\mathrm{pH} 6$ by dil. $\mathrm{HCl}$ ). Since ziyu-glycoside I is hardly soluble in water, the cultivation was performed on a suspension with shaking once a day and it took longer period (27 days) than the previous cases $(\sim 2$ weeks).1,2,4) The total culture broth was extracted with ether three times and then with $n$-BuOH. Ether extract, after the usual work-up, gave a product $(150 \mathrm{mg})$ which was purified by preparative TLC developing with $\mathrm{CHCl}_{3}-\mathrm{MeOH}(10: 1)$ to furnish P-A $(R f: 0.55 ; 34.3 \mathrm{mg})$ and P-B (Rf: $0.40 ; 29.7 \mathrm{mg})$. On the other hand, $n-\mathrm{BuOH}$ extract afforded recovered ziyu-glycoside I (440 mg).

P-A (XI), mp $274-275^{\circ}$ (fine crystals from $\left.\mathrm{MeOH}\right),[\alpha]_{\mathrm{D}}+30^{\circ}(c, 0.34, \mathrm{EtOH})$. Anal. Calcd. for $\mathrm{C}_{30^{-}}$ $\mathrm{H}_{48} \mathrm{O}_{4} \cdot \mathrm{H}_{2} \mathrm{O}: \mathrm{C}, 73.43 ; \mathrm{H}, 10.27$. Found: $\mathrm{C}, 73.19 ; \mathrm{H}, 10.05$. IR $\nu_{\max }^{\mathrm{KBr}} \mathrm{cm}^{-1}: 3450(\mathrm{OH}), 1685(\mathrm{COOH}), 1025$. $\mathrm{UV}(\mathrm{EtOH})$; end absorption. Mass Spectrum $m / e: 472\left(\mathrm{M}^{+}, 9 \%\right), 454\left(\mathrm{M}^{+}-\mathrm{H}_{2} \mathrm{O}, 12 \%\right), 439\left(\mathrm{M}^{+}-\mathrm{H}_{2} \mathrm{O}_{-} \mathrm{CH}_{3}\right.$, $8 \%$ ), 264 (ii, 16\%), 207 (i, 40\%), $146(100 \%)$.

Methylation of P-A $(10 \mathrm{mg})$ with diazomethane in ether followed by repeated recrystallization with $\mathrm{MeOH}$ yielded colorless leaflets $(7 \mathrm{mg}), \mathrm{mp} 127-128.5^{\circ},[\alpha]_{\mathrm{D}}+39.7^{\circ}\left(c, 0.35, \mathrm{CHCl}_{3}\right)\left(\mathrm{Lit}^{11 d}\right)$ methyl pomolate, $\left.\operatorname{mp} 126-128^{\circ},[\alpha]_{\mathrm{D}}+38.5^{\circ}\left(c, 2.0, \mathrm{CHCl}_{3}\right)\right)$. IR $\nu_{\max }^{\mathrm{KBr}} \mathrm{cm}^{-1}: 3450(\mathrm{OH}), 1720,1260,1225\left(\mathrm{COOCH}_{3}\right), 1030$. Mass Spectrum m/e: $486\left(\mathrm{M}^{+}, 8 \%\right), 468\left(\mathrm{M}^{+}-\mathrm{H}_{2} \mathrm{O}, 9 \%\right), 453\left(\mathrm{M}^{+}-\mathrm{H}_{2} \mathrm{O}-\mathrm{CH}_{3}, 5 \%\right), 426\left(\mathrm{M}^{+}-\mathrm{HCOOCH}_{3}, 21 \%\right)$, $278(8 \%), 207(31 \%)$ (ions derived from the reverse Diels-Alder fragmentation $\left.{ }^{11 d}\right)$ ), $179(100 \%)$. The methyl ester obtained here was found identical with authentic methyl pomolate $\left.(\mathrm{XV})^{11 d}\right)$ by the direct comparison (mixed mp, IR (KBr), and TLC).

Treatment of $\mathrm{P}-\mathrm{A}$ (TLC scale) with $3 \% \mathrm{HCl}-\mathrm{MeOH}$ by refluxing $30 \mathrm{~min}$ followed by the usual work-up furnished a mixture containing the dehydrated products as revealed by TLC.

$\mathrm{P}-\mathrm{B}, \mathrm{mp} 243-245^{\circ}$ (colorless crystals from $\left.\mathrm{MeOH}\right),[\alpha] \mathrm{D}+25^{\circ}(c, 0.23, \mathrm{DMSO}), \mathrm{IR} \nu_{\max }^{\mathrm{KBr}} \mathrm{cm}^{-1}: 3450$ (br) $(\mathrm{OH}), 1685(\mathrm{COOH}), 1080$. The substance obtained here was identified with ziyu-glycoside II (II) described above by mixed $\mathrm{mp}$, IR (KBr), and TLC.

Methylation of Ziyu-Glycoside II (II) followed by Acetylation giving XVI-i) Diazomethane treatment of II $(30 \mathrm{mg})$ in ether-MeOH mixture for $4 \mathrm{hr}$ followed by recrystallization with EtOAc furnished colorless needles of ziyu-glycoside II methyl ester (XVII) $(26 \mathrm{mg}), \mathrm{mp} 176-180^{\circ},[\alpha]_{\mathrm{D}}+23^{\circ}\left(c, 0.32, \mathrm{CHCl}_{3}\right)$. Anal. Calcd. for $\mathrm{C}_{36} \mathrm{H}_{58} \mathrm{O}_{8} \cdot \mathrm{H}_{2} \mathrm{O}: \mathrm{C}, 67.89 ; \mathrm{H}, 9.50$. Found: C, 67.90; H, 9.24. IR $\nu_{\max }^{\mathrm{KBr}} \mathrm{cm}^{-1}: 3450(\mathrm{br})$ $(\mathrm{OH}), 1715,1255,1225\left(\mathrm{COOCH}_{3}\right), 1080$. Mass Spectrum $m / e: 618\left(\mathrm{M}^{+}, 2 \%\right), 600\left(\mathrm{M}^{+}-\mathrm{H}_{2} \mathrm{O}, 3 \%\right), 179(100 \%)$.

ii) A solution of ziyu-glycoside II methyl ester (XVII) $(14 \mathrm{mg})$ in pyridine $(0.4 \mathrm{ml})$ and $\mathrm{Ac}_{2} \mathrm{O}(0.2 \mathrm{ml})$ was kept for $24 \mathrm{hr}$ at room temp. (r.t.), poured into ice-water and extracted with ether. The treatment of the extract in a usual manner gave a product (XVI) $(14 \mathrm{mg}$, single spot on TLC, but the crystallization was without success $),[\alpha]_{\mathrm{D}}+28^{\circ}\left(c, 0.55, \mathrm{CHCl}_{3}\right)$. Anal. Calcd. for $\mathrm{C}_{42} \mathrm{H}_{64} \mathrm{O}_{11}: \mathrm{C}, 67.71 ; \mathrm{H}, 8.52$. Found: $\mathrm{C}, 67.72 ; \mathrm{H}, 8.90$. IR $\nu_{\max }^{\mathrm{CCl}_{4}} \mathrm{~cm}^{-1}: 3615$ (w.) $(\mathrm{OH}), 1760,1245,1220\left(\mathrm{COOCH}_{3}, \mathrm{OCOCH}_{3}\right)$. NMR $\left(\mathrm{CDCl}_{3}, 100\right.$ $\mathrm{MHz}) \tau: 9.33,9.26,9.11,9.08,9.05,8.81\left(18 \mathrm{H}\right.$, totally $\left.\mathrm{CH}_{3} \times 6\right), 8.77\left(3 \mathrm{H}, \mathrm{s},>\mathrm{C}_{(19)}(\mathrm{OH}) \mathrm{CH}_{3}\right), 8.01,7.98$, $7.90\left(3 \mathrm{H}\right.$ each $\left.\mathrm{s},-\mathrm{OCOCH}_{3} \times 3\right), 7.44\left(1 \mathrm{H}, \mathrm{br} \mathrm{s}, W \frac{\mathrm{h}}{2}=5 \mathrm{~Hz}, \mathrm{C}_{(18)}-\mathrm{H}\right), 6.93\left(1 \mathrm{H}, \mathrm{t}-\mathrm{like}, \mathrm{C}_{(3)}-\alpha \mathrm{H}\right), 6.44(3 \mathrm{H}, \mathrm{s}$, $\left.\mathrm{COOCH}_{3}\right), 6.23\left(2 \mathrm{H}\right.$ center, $\mathrm{AB}$ part in $\mathrm{ABX}$ system, $\left.\mathrm{C}_{\left(5^{\prime}\right)}-\mathrm{H}_{2}\right),{ }^{24)} 5.59\left(1 \mathrm{H}\right.$, d-like, $J=7 \mathrm{~Hz}, \mathrm{C}_{\left.\left(1^{\prime}\right)-\mathrm{H}\right), 4.64-}$ $5.02\left(4 \mathrm{H}, \mathrm{C}_{(12)}, \mathrm{C}_{\left(2^{\prime}\right)}, \mathrm{C}_{\left(3^{\prime}\right)}, \mathrm{C}_{\left(4^{\prime}\right)}-\mathrm{H}_{4}\right)$. Mass Spectrum $m / e: 744\left(\mathrm{M}^{+}, 1 \%\right), 726\left(\mathrm{M}^{+}-\mathrm{H}_{2} \mathrm{O}, 3 \%\right), 711\left(\mathrm{M}^{+}-\mathrm{H}_{2} \mathrm{O}-\right.$ $\mathrm{CH}_{3}, 0.6 \%$ ), 468 (iii, $29 \%$ ), 259 (iv, $66 \%$ ), $179(100 \%)$.

24) The $J$ value is obscure due to the overlapping with the signal of $\mathrm{COOCH}_{3}$. 
Attempted Smith Degradation (the de Mayo's Modification ${ }^{22)}$ ) of Ziyu-Glycoside I (I) — A mixture of $\mathrm{I}(1 \mathrm{~g})$ in $\mathrm{MeOH}(50 \mathrm{ml})$ and water $(50 \mathrm{ml})$ was treated with $\mathrm{NaIO}_{4}$ aq. solution $(1.5 \mathrm{~g}$ in $20 \mathrm{ml}$ water $)$ under ice-cooling in $30 \mathrm{~min}$. After keeping r.t. for further $24 \mathrm{hr}$, methanol was removed under the reduced pressure and the residue was diluted with water and extracted with ether. Ether extract was then washed with $5 \%$ aq. $\mathrm{Na}_{2} \mathrm{~S}_{2} \mathrm{O}_{3}$, water and dried over $\mathrm{MgSO}_{4}$ and treated in a usual manner affording a crude product. The product was then dissolved in $2 \% \mathrm{KOH}-\mathrm{EtOH}$ and refluxed 90 min under $\mathrm{N}_{2}$ atmosphere. After cooling, the reaction mixture was adjusted to $\mathrm{pH} 4$ by dil. $\mathrm{H}_{2} \mathrm{SO}_{4}$, extracted with ether and treated as usual to furnish a final product $(519 \mathrm{mg})$, which consisted of a complex mixture as revealed by TLC developing with benzene-EtOAc $(1: 1)$ and therefore, the further purification was abandoned.

Fully Methylation of Ziyu-Glycoside I (I) followed by Methanolysis-1) Methylation after the Hakomori's procedure ${ }^{16)}$ : A mixture of $\mathrm{NaH}(0.5 \mathrm{~g}$, washed with petr. ether 3 times beforehand) and DMSO $(3 \mathrm{ml})$ was heated $1 \mathrm{hr}$ with stirring at $70-80^{\circ}$. After cooling to r.t., a solution of $\mathrm{I}(100 \mathrm{mg})$ in DMSO (5 ml) was added to the above solution and the mixture was kept stirring at r.t. for $1 \mathrm{hr}$, and added with $\mathrm{CH}_{3} \mathrm{I}(7 \mathrm{ml})$ while keeping the reaction temp. at $20-25^{\circ}$. The total mixture was stirred further $10 \mathrm{hr}$ at r.t., poured into water, extracted with $\mathrm{CHCl}_{3}$, and the extract was treated in a usual manner to give a crude product, which was methylated again in the same manner as above giving a final product $(70 \mathrm{mg})$. The product was then purified by passing through a column of silica gel eluting with $\mathrm{CHCl}_{3}$ furnishing the fully methylated product (20 mg, syrupy).

ii) Methanolysis: A mixture of the above methylation product $(20 \mathrm{mg})$ in anhydrous $2 \mathrm{~N} \mathrm{HCl}-\mathrm{MeOH}$ $(10 \mathrm{ml})$ was refluxed $4 \mathrm{hr}$. After cooling, methanol was removed under the reduced pressure and the resulting product was treated with water and extracted with $\mathrm{CHCl}_{3}$. The $\mathrm{CHCl}_{3}$ extract, after the usual workup, gave a syrup $(12.5 \mathrm{mg})$, which was then chromatographed over silica gel. From the fractions eluted with benzene-acetone $(9: 1)$ was identified methyl 2,3,4-tri-O-methyl-L-arabopyranoside and methyl 2,3,4,6tetra-O-methyl-D-glucopyranoside by GLC. ${ }^{25)}$

Acknowledgement The authors would like to express their sincere thankness to Prof. T. Kawasaki of Kyūshū University for the fruitful discussion. They are also grateful for the authentic specimens to Prof. C.H. Brieskorn of Würzburg University (methyl pomolate), to Prof. T. Takemoto of Tōhoku University (tomentosolic acid and methyl 3-O-acetyl-tomentosolate), and to Prof. T. Kawasaki (methyl glucoside methyl ether and methyl arabinoside methyl ether) for the comparison purpose. They thank also Mr. M. Tanioka of this faculty for the mass spectra, the Res. Lab. of Takeda Chem. Ind. for the NMR measurement (100 $\mathrm{MHz}$, Prof. I. Ninomiya of Kobe Women's College of Pharmacy for the NMR measurement (60 MHz), the Res. Lab. of Dainippon Pharm. Co. for the elemental analyses, and the Hoansha for the research grant.

25) Condition: $15 \%$ diethyleneglycol succinate on chromosorb $W$ column, temp. $201^{\circ}$, using Shimazu GC-1C Gas Chromatograph equipped with the hydrogen flame ionization detector, detector temp. $225^{\circ}$, $\mathrm{N}_{2}$ gas flow rate $15 \mathrm{ml} / \mathrm{min}$. 